\title{
PHYSICAL TRAINING PREVENT AND TREAT HEPATIC LIPID ACCUMULATION INDUCED BY FRUCTOSE-RICH DIET
}

\author{
TREINAMENTO FÍSICO PREVINE E TRATA ACUMULAÇÃO LIPÍDICA HEPÁTICA \\ INDUZIDA POR DIETA RICA EM FRUTOSE
}

\begin{abstract}
Rafael Calais GASPAR ${ }^{1}$; Gabriel Keine KUGA ${ }^{2}$; Vitor Rosetto MUÑOZ ${ }^{1}$; Andressa COOPE; Lucieli Teresa CAMBRI ; Ana Carolina GHEZZI ${ }^{3}$; Leandro Pereira de MOURA ${ }^{1,2}$; José Alexandre Curiacos de Almeida LEME ${ }^{5}$; José Rodrigo PAULI ${ }^{1}$; José Diego BOTEZELLI ${ }^{1}$

1. Department of Nutrition, Metabolism and Exercise, University of Campinas (UNICAMP), Limeira - SP, Brazil. jdbotezelli@outlook.com; 2 Universidade Estadual Paulista Julio de Mesquita Filho, Post-graduate program in Movement Sciences; 3. Medical Sciences University, University of Campinas (UNICAMP), Campinas - SP, Brazil.; 4. Department of Physical Education, Federal University of Mato Grosso (UFMT), Cuiabá - MT, Brazil; 5. Department of Physical Education, Catholic University Center Auxilium UniSalesiano, Lins - SP, Brazil.
\end{abstract}

\begin{abstract}
This study aims to examine the effects of physical training performed in early (preventive) or late (therapeutic) protocols on body weight gain, glucose tolerance, and triglycerides accumulation in rats fed on a fructoserich diet. Wistar rats were allocated into two major groups according to the diet received: Control (C- standard diet) and Fructose (F- diet containing 60\% fructose) fed during 120 days. Next, these two groups were distributed into six groups: C and F that were kept inactive; CTE (Control Trained Early) and FTE (Fructose Trained Early) that were submitted to Anaerobic Threshold (AnT) training from 28 to 120 days; CTL (Control Trained Late) and FTL (Fructose Trained Late) trained from 90 to 120 days. Physical Training was composed by swimming (5 days/week) at AnT determined by maximum lactate stead state (MLSS). The Oral Glucose Tolerance Test (oGTT) was performed 48h after the last in vivo analysis and did not showed differences between the groups. After, the animals were euthanized for heart, liver, and adipose tissue extraction. The early exercised animals had lower body weight compared to their sedentary littermates. Also, the fructose-rich diet increased liver lipids content in the sedentary animals and physical training successfully reduced this parameter in both major groups. These results suggests that physical training at the AnT performed in early or late protocols are effective to prevent and treat metabolic disorders related to fructose intake.
\end{abstract}

KEYWORDS: Physical Exercise. Overweight. Adiposity. Hepatic Steatosis.

\section{INTRODUCTION}

The Metabolic Syndrome (MS) covers a spectrum of insulin related disorders. These changes include obesity, glucose intolerance, type 2 Diabetes Mellitus, hypertension, dyslipidemia, endothelial dysfunction, fatty-liver, and others (FALL; INGELSSON, 2014). The main components of MS that affects many countries around the world are increased consumption of fructose and saturated fats, associated to increased caloric intake, and decreased physical activity, also contributing to overweight (BRAY; NIELSEN; POPKIN, 2004).

Experimental animal models have been widely applied to investigate the effects of western diet on MS components. For this approach, fructoserich diet have been used as an experimental model of MS risk (BOTEZELLI et al., 2016; LEE et al., 2006; NAGAI et al., 2002). Rats submitted to a high fructose diet develops several features of MS including development of hepatic steatosis, insulin resistance, hyperinsulinemia, hypertriglyceridemia and hypertension (STOIANOV; ADELI, 2014; TRAN; YUEN; MCNEILL, 2009). This kind of research provides interesting experimental background to investigate the effects of new interventions against several diseases (ANGELIS et al., 2017).

On the other hand, an interesting therapeutic strategy to prevent or treat disorders like MS is the practice of physical exercise. It was previously demonstrated that physical exercise improves glucose tolerance and reduces insulin resistance in animals fed a fructose-rich diet (BOTEZELLI et al., 2016). However, few studies involving MS utilized physical training with intensity and duration controlled, increasing the doubts about if the physical training exerts prophylactic, therapeutic or both actions in relation to MS (BOTEZELLI et al., 2009). Thus, the present research aims to evaluate the effects of Physical Training in intensity at AnT (determined by the Maximal Lactate Steady State test) in two different periods, early and late in rats fed with fructose-rich diet, on important components of the MS. Therefore, this research aimed to provide a better understanding about the role of physical exercise as a preventive (early) or therapeutic (late) role against body weight gain, 
adipose tissue hypertrophy and fatty-liver disease.

\section{MATERIAL AND METHODS}

\section{Animals and procedures}

Weaning Wistar rats (28 days old, $\mathrm{n}=48$ ) were kept in collective cages (four animals per cage) at a controlled temperature of $25 \pm 1{ }^{\circ} \mathrm{C}$ and under a light/dark cycle of $12 / 12 \mathrm{~h}$ with free access to water and food. The experiment was performed at the Nutrition, Metabolism and Exercise Laboratory at São Paulo State University (Unesp), Rio Claro, Brazil. Labina, Purina ${ }^{\circledR}$ commercial chow was used as a standard diet $(57.3 \%$ carbohydrate, $41.2 \%$ of cornstarch) (REEVES, 1997). For the fructose-rich diet, we used an adapted diet standardized by Bezerra and colleagues (BEZERRA et al., 2001) composed of (in $\mathrm{g} / \mathrm{kg}$ ) 202 of casein, 628.5 of fructose (62.8\%), 2 of 1-cysteine, 70 of soy oil, 35 of mineral salt mix 10 of a vitamin mix, 50 of fiber and 2.5 of choline chloridrate. All experiments were analyzed and approved by the Biosciences Institute Animal Ethics Committee, Rio Claro Unesp Campus (case number: 005/2010).

From the weaning ( $28 \mathrm{~d}$ ) until the adulthood (120d), the animals were divided in two major
GASPAR, R. C. et al.

groups according to the diet: Control $(C)$ : chow diet, or Fructose (F): fructose-rich diet. Eight animals of each diet groups were subjected to a swimming training from the $28 \mathrm{~d}$ to $120 \mathrm{~d}$ at the AnT intensity (CTE and FTE subgroups). Another eight animals of each major group was then, subjected from $90 \mathrm{~d}$ to $120 \mathrm{~d}$ to a swimming training at Maximal Lactate Steady State (MLSS) intensity (CTL and FTL subgroups). The last eight animals of each major group (C or F) did not perform physical exercise (sedentary subgroups). At the end of experiments, we had the follow 6 experimental subgroups: Control $(C)$ : fed on a chow diet and kept sedentary, Control Trained Earlier (CTE): fed on a chow diet and subjected to a MLSS swimming training from $28 \mathrm{~d}$ to $120 \mathrm{old}$, Control Trained Late (CTL): fed on a chow diet and subjected to a MLSS swimming training from $90 \mathrm{~d}$ to 120 old, Fructose $(F)$ : fed on a fructose-rich diet and kept sedentary, Fructose Trained Earlier (FTE): fed on a fructoserich diet and subjected to a MLSS swimming training from $28 \mathrm{~d}$ to $120 \mathrm{old}$, Fructose Trained Late ( $F T L$ ): fed on a fructose-rich diet and subjected to a MLSS swimming training from $90 \mathrm{~d}$ to $120 \mathrm{old}$.

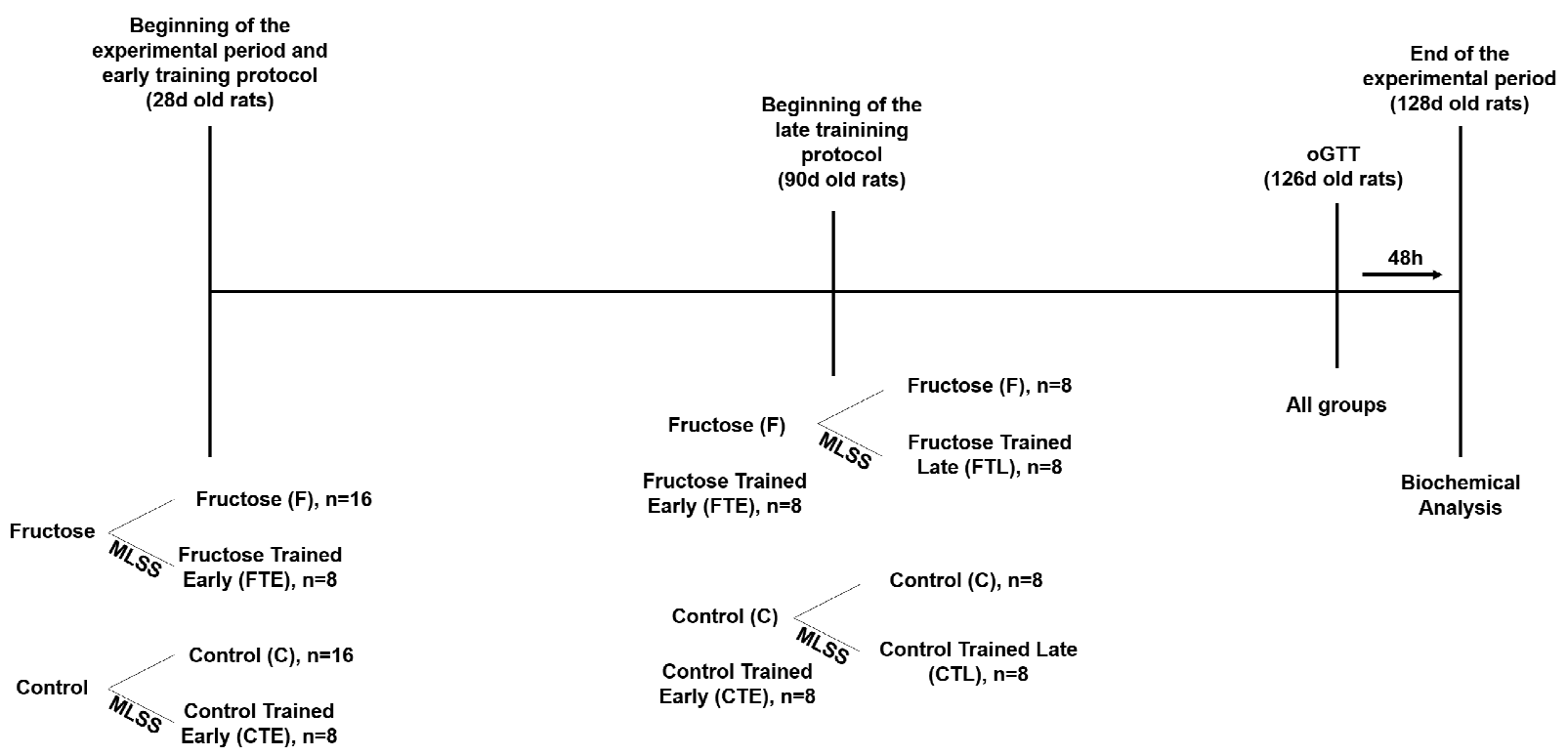

Figure 1. Experimental Design. The MLSS test was performed at 28d (early) and 90d (late) to determine the distribution of the six groups during the experimental period. At 28d, the Fructose groups received the fructose-rich diet, and the Control groups continued with chow diet. A MLSS test was performed at experimental day 28 to determine the exercise intensity to begin the early exercise protocol for CTE $(n=8)$ and FTE $(n=8)$ groups. Another MLSS test was performed at experimental day 90 to determine the exercise intensity to begin the late exercise protocol for CTL $(n=8)$ and FTl $(n=8)$ groups. Each group (F, FTE, FTL, C, CTE, CTL) was composed by 8 animals at the end of the experimental period. 


\section{Swimming Exercise Adaptation and Physical Training Protocol}

All animals were firstly adapted to the water environment. Adaptation was performed over seven consecutive days without load in the same tank (50 $\mathrm{cm}$ deep) where the physical training was performed, with the water temperature at $31 \pm 1^{\circ} \mathrm{C}$. Animals of CTE and FTE groups were adapted from the $20 \mathrm{~d}$ to $27 \mathrm{~d}$ old. Animals from CTL and FTL groups were adapted from $80 \mathrm{~d}$ to $87 \mathrm{~d}$ old. The animals of exercise groups swam five days per week for one hour at the AnT with a bag attached to the thorax containing the workload corresponding to the MLSS. The workload was adjusted weekly according to the body weight of the animal.

\section{Anaerobic Threshold (AnT)}

The Maximal Lactate Steady State (MLSS) test was used to determine the AnT. In nonconsecutive days the animals were subjected to four swimming tests, and the protocol utilized was adapted from a previously described method (GOBATTO et al., 2001). Each test consisted of thirty minutes of continuous swimming supporting the workload, with blood collection by a small cut at the tip of the tail every five minutes to determine the concentrations of lactate. The blood lactate concentrations were determined by a spectrophotometer. The criterion used for stabilization was a difference less than or equal to $1.0 \mathrm{mM}$ of blood. The MLSS test was performed in the beginning (day 28) for all groups to determine the load and at the 90 day of the experimental period for CTE, CTL, FTE and FTL groups.

\section{Food and Water Intake}

The animals body weight, food and water ingestion were registered once a week (BOTEZELLI et al., 2010) during the twelve weeks of experimental period. Then, the Area Under the Curve (AUC) of whole experimental period (120 days) was calculated using the Microsoft ${ }^{\circledR}$ Excel 2013 software through the trapezoidal method (MATTHEWS et al., 1990).

\section{Oral Glucose Tolerance Test (oGTT)}

At the end of experiment (120d) we performed an oGTT in all groups. After fasting of $15 \mathrm{~h}$, a $25 \mu \mathrm{L}$ blood sample was collected from the tail of animals ( $\mathrm{t} 0)$. Later, a $20 \%$ glucose solution ( $2 \mathrm{~g} / \mathrm{kg}$ body weight) was administered to rats by a polyethylene gastric tube. Blood samples were collected after 30, 60 and 120 min by heparinized capillary tubes calibrated for $25 \mu \mathrm{L}$ to evaluate the glucose concentrations by the glucose oxidase method (NOGUEIRA et al., [s.d.]). Results were analyzed by establishing the serum glucose AUG values by means of the Matthews trapezoidal rule using Microsoft ${ }^{\circledR}$ Excel 2007 (MATTHEWS et al., 1990).

\section{Biological Samples}

Forty eight hours after the last in vivo analysis, animals were euthanized in a $\mathrm{CO}_{2}$ chamber. Then, the heart, the liver, and the adipose tissue (mesenteric, retroperitoneal and subcutaneous) were extirpated to measure the weight and lipids concentration dosage. The lipid extraction and determination was previously described (BOTEZELLI et al., 2010; NOGUEIRA et al., [s.d.]). The tissue samples were placed in tubes containing $0.5 \mathrm{ml}$ of $0.1 \%$ Triton X-100, homogenized (45s), and centrifuged (1700 rcf by 10 minutes) (BOTEZELLI et al., 2010). The supernatant was collected for the triglyceride measurement.

\section{Statistical analyses}

For the statistical tests and graphs, we used the software Statistica $7.0^{\circledR}$.The Shapiro-Wilk's W test was used to verify the normality of the data. The results were analysed using ANOVA two-way with Bonferroni post-hoc test (Bonferroni). All results are expressed as MEAN \pm standard deviation (SD). The significance level was set at 0.05 .

\section{RESULTS}

The MLSS was performed at the beginning of the experimental period for all of the animals. Figure 2 shows the blood lactate concentrations (mM: millimolar) and workload used as a MLSS test example. Most of the animals (44\%) reached the MLSS in the 28th day of life at $9 \%$ of body weight and the workloads spread between $8-9.5 \%$ of body weight.

Table 1 shows the area under curve (AUC) results for body weight, food intake and water intake during the experiment. Early training provide a reduction in body weight AUC when compared to littermate control (C and $\mathrm{F})$ and an increasing in food and water intake compared to all other groups (C, CTL, F and FTL). Last, animals fed on a fructose-rich diet (F, FTE, and FTL) showed higher food and water intake compare to chow diet (C, CTE and CTL). 


\section{Lactate during MLSS Test}

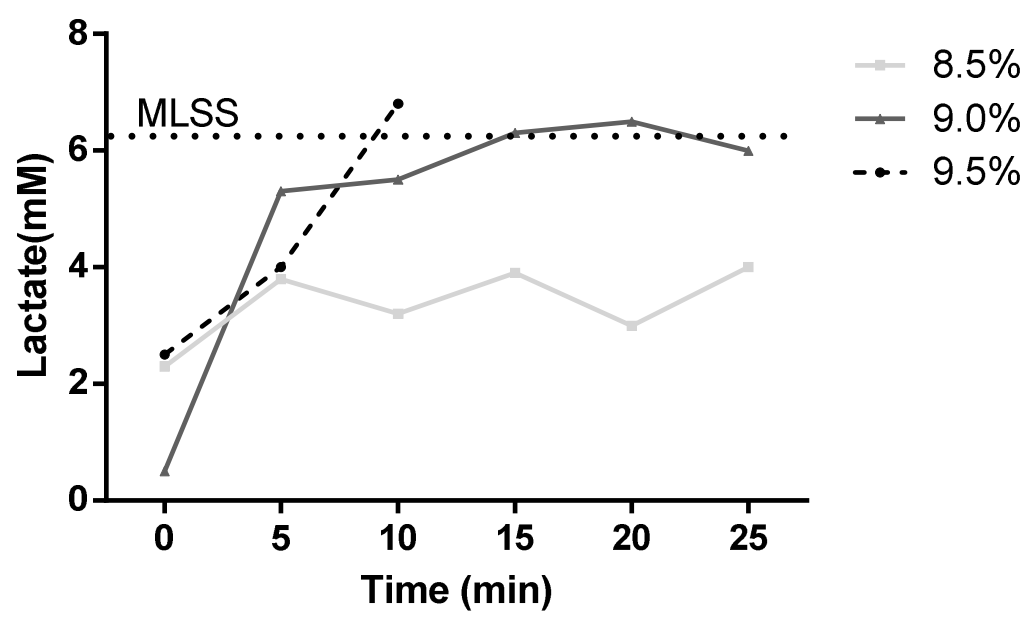

Figure 2. Lactate during MLSS test. Blood lactate representation of maximum lactate stead state (MLSS) test of one animal with 28d. For this particular animal, the MLSS was achieved at 9.0\% of Body Weight.

Table 1. Area Under the Curve (AUC) of body weight, food and water intake after twelve weeks experiment. Results expressed as Mean \pm SD. N= 8 animals per group.g*120g: Accumulated body weight during 120 days. C: Control, CTE: Control Trained Earlier, CTL: Control Trained Late, F: Fructose, FTE: Fructose Trained Earlier, FTL: Fructose Trained Late. $\mathrm{p} \leq 0.05$ Two-way ANOVA, Bonferroni post hoc. ${ }^{*} \neq \mathrm{C},{ }^{\prime} \neq \mathrm{CTE}, \stackrel{\sharp}{*} \neq \mathrm{CTL},{ }^{\sharp} \neq \mathrm{F}$.

\section{Groups}

Parameters

\begin{tabular}{llllll}
\hline $\mathrm{C}$ & $\mathrm{CTE}$ & $\mathrm{CTL}$ & $\mathrm{F}$ & FTE & FTL
\end{tabular}

\begin{tabular}{lcccccc}
\hline $\begin{array}{l}\text { Body Weight AUC } \\
\text { (g*120d) }\end{array}$ & $3975 \pm 302$ & $3395 \pm 343^{*}$ & $3741 \pm 313$ & $3751 \pm 312$ & $3172 \pm 209^{\#}$ & $3319 \pm 257$ \\
$\begin{array}{l}\text { Food Intake AUC } \\
\text { (g*120d) }\end{array}$ & $55.9 \pm 3.2$ & $72.9 \pm 2.7^{*}$ & $55.8 \pm 3.4^{\rfloor}$ & $65.3 \pm 4.2^{*}$ & $91.2 \pm 9.7^{\# !}$ & $67.1 \pm 4.0^{\ddagger}$ \\
$\begin{array}{l}\text { Water Intake AUC } \\
\text { (g*120d) }\end{array}$ & $84.5 \pm 4.4$ & $122.5 \pm 9^{*}$ & $85.5 \pm 4.6^{\jmath}$ & $104.8 \pm 9.9^{*}$ & $155 \pm 7.4^{\# !}$ & $117 \pm 6.5^{\# ¥}$ \\
\hline
\end{tabular}

Figure 3 shows the oral glucose tolerance test after 15 hours fasting. There is no difference between the groups.

Triglycerides contents in adipose tissue, liver and heart $(\mathrm{mg} / \mathrm{dL})$ is showed in Table 2 . Neither diet nor physical exercise (both early and late protocol) promoted change in the lipids content in adipose tissue and heart. However, in the liver, occurred an increase in lipid concentrations in fructose group (F) compared to control group (C). On the other hand, fructose-trained animals (FTE and FTL) showed reduction in liver lipid content compared to F group.

Adipose tissue weight is showed in Figure 4, indicating that early trained (CTE and FTE) animals showed no difference when compared to late trained animals (CTL and FTL). 

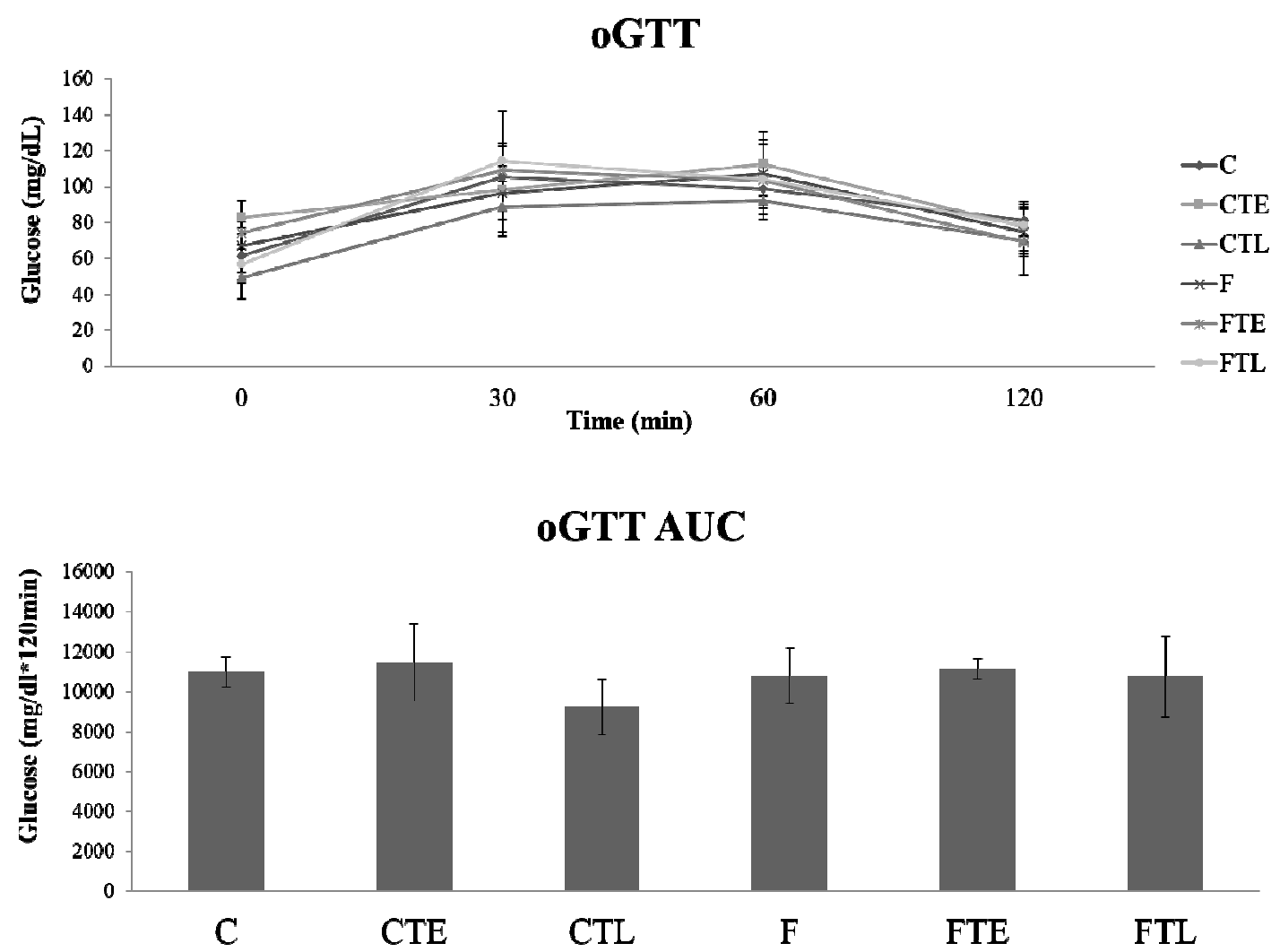

Figure 3. Area Under the Curve (AUC) of oral Glucose Tolerance Test. Glycaemia kinetics and area under curve of blood glucose during oGTT at the end of experimental period. Results expressed as Mean+SD. N= 8 animals per group. C: Control, CTE: Control Trained Earlier, CTL: Control Trained Late, F: Fructose, FTE: Fructose Trained Earlier, FTL: Fructose Trained Late. $\mathrm{p} \leq 0.05$ Two-way ANOVA, Bonferroni post hoc test.

Table 2. Total lipids (umol/mg) content in heart, liver, subcutaneous, mesenteric, and retroperitoneal adipose tissue. Results expressed as Mean \pm SD. $N=8$ animals per group. C: Control, CTE: Control Trained Earlier, CTL: Control Trained Late, F: Fructose, FTE: Fructose Trained Earlier, FTL: Fructose Trained Late. $\mathrm{p} \leq 0.05$ Two-way ANOVA, Bonferroni post hoc test. ${ }^{*} \neq \mathrm{C},{ }^{f} \neq \mathrm{CTE},{ }^{\sharp} \neq \mathrm{CTL},{ }^{\sharp} \neq \mathrm{F},{ }^{f} \neq \mathrm{FTE}$.

\begin{tabular}{lllllll}
\hline Tissue/Total Lipids (umol/mg) & C & CTE & CTL & F & FTE & FTL \\
\hline Mesenteric Adipose Tissue & $18 \pm 4,1$ & $21,2 \pm 6$ & $23,1 \pm 5,0$ & $20,0 \pm 3,6$ & $26,5 \pm 5,7$ & $19,0 \pm 2,6$ \\
Retroperitoneal Adipose Tissue & $39,3 \pm 5,1$ & $47,7 \pm 7,1$ & $39,8 \pm 4,5^{\rfloor}$ & $45,0 \pm 9,5$ & $41,7 \pm 2,9$ & $42,7 \pm 6,1$ \\
Subcutaneous Adipose Tissue & $35,8 \pm 4,4$ & $31,4 \pm 5,9$ & $35,3 \pm 6,2$ & $34,6 \pm 3,9$ & $31,3 \pm 4,9$ & $34,8 \pm 2,7$ \\
Liver Adipose Tissue & $5,9 \pm 1,2$ & $4,6 \pm 0,3^{*}$ & $6,0 \pm 1,8$ & $7,7 \pm 0,5^{*}$ & $5,5 \pm 1,6^{\#}$ & $5,9 \pm 1,7^{\#}$ \\
Heart Adipose Tissue & $7,7 \pm 1,4$ & $8,6 \pm 1,2$ & $7,9 \pm 1,3$ & $8,3 \pm 1,6$ & $9,3 \pm 1,5$ & $8,7 \pm 1,8$ \\
\hline
\end{tabular}




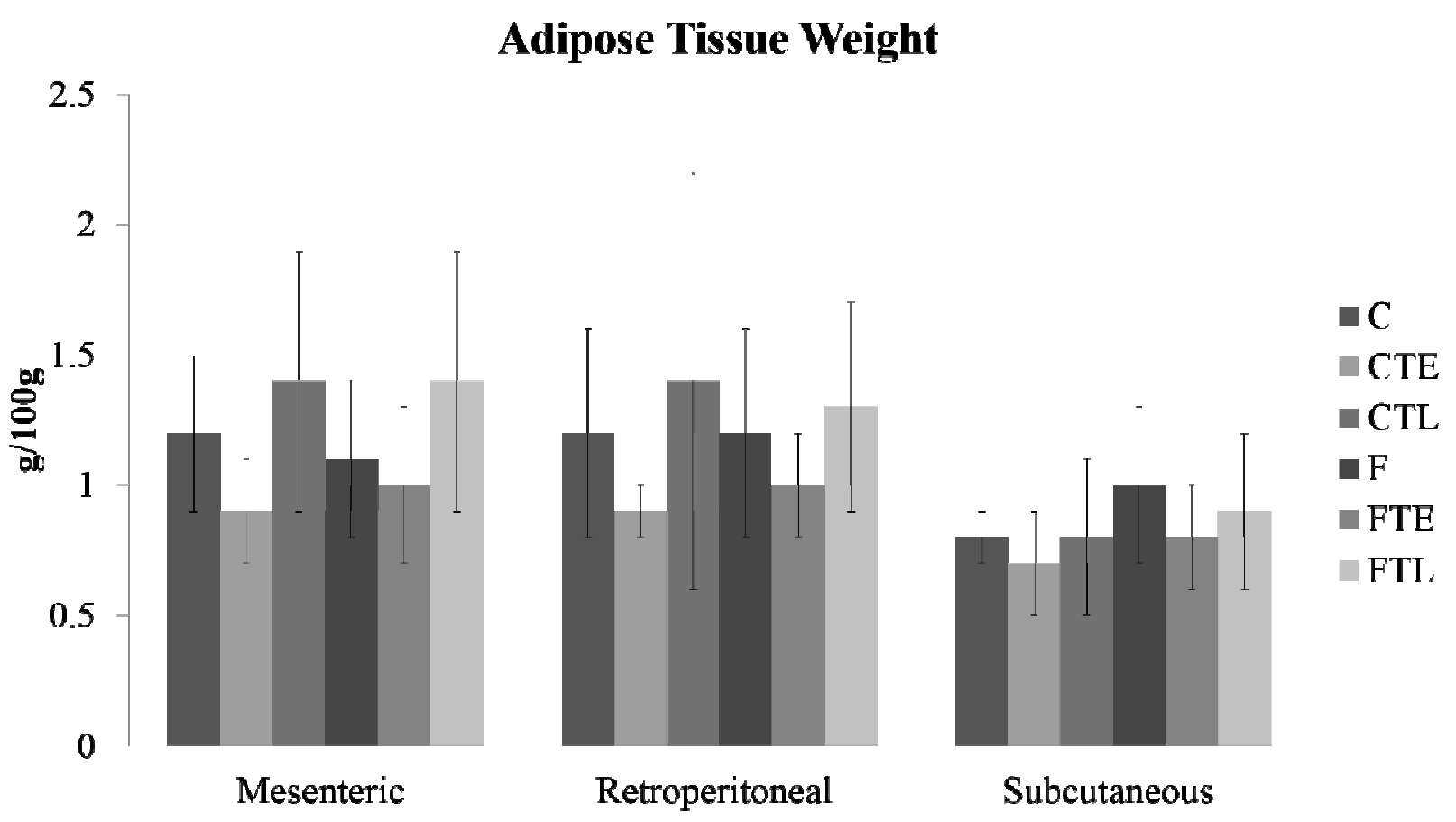

Figure 4. Adipose Tissue Weight. Mesenteric, retroperitoneal and subcutaneous adipose tissue regions $(\mathrm{g} / 100 \mathrm{~g})$ in the groups after the experimental period. Results expressed as Mean $\pm \mathrm{SD}$. $\mathrm{N}=8$ animals per group. C: Control, CTE: Control Trained Earlier, CTL: Control Trained Late, F: Fructose, FTE: Fructose Trained Earlier, FTL: Fructose Trained Late. $\mathrm{p} \leq 0.05$ Two-way ANOVA, Bonferroni post hoc test.

\section{DISCUSSION}

Fructose, glucose and saturated fatty-acids consumption, along with sedentary life style, are the most important contributors to increased incidence of overweight, obesity, type 2 Diabetes Mellitus, coronaries diseases and some type of cancers (FALL; INGELSSON, 2014). The entire global population has shown in the last two decades an increase in metabolic disorders (BRAY; NIELSEN; POPKIN, 2004; CHENG, 2003; LÓPEZJARAMILLO et al., 2014; MCLELLAN, 2002). To contribute with new perspectives to prevent or treat these disorders, the present research investigated the effects of the physical exercise performed at AnT on weight gain and triglycerides accumulation in animals fed on a fructose-rich diet. To our knowledge, this is the first study that uses exercise at AnT in both the prevention (early protocol) and treatment (late protocol) of classic MS markers.

The results presented in the present study shows no difference in oral glucose tolerance test (oGTT), which corroborates the findings of Fields et al. (FIELDS; LEWIS; LURE, 1996) that submitted Wistar rats to fructose diet (62\%) during two weeks. On the other hand, Blakely and et al. (BLAKELY et al., 1981) demonstrated a reduction in glucose tolerance in animals submitted to fructose diet
(15\%) for 15 months. These studies and the results of the present study suggests the 12 weeks period of fructose diet was not enough to impair the glucose tolerance in young rats.

We also evaluated the food intake of the animals. Fructose fed animal groups (F, FTE, FTL) showed increased food intake (AUC) compared to respective controls. In addition, the CTE and FTE groups also showed an increase in food intake when compared to sedentary control groups (C and F). The exercise-increased energy expenditure stimulates food intake to reestablish energy stores. The increased food intake observed in trained rats corroborates other studies, which showed the crucial role of exercise in the modulation of energy balance (EBAL et al., 2007; LEVIN; DUNN-MEYNELL, 2002).

The physical exercise is crucial in the control of body weight (BOUCHARD et al., 1994). The present study shows that trained earlier groups (CTE and FTE) have a decreased body weight (AUC) if compared to sedentary controls ( $\mathrm{C}$ and $\mathrm{F}$ groups). This finding is interesting, once that trained earlier rats also show an increase in food intake compared to sedentary controls ( $\mathrm{C}$ and $\mathrm{F}$ groups) and to trained late rats (CTL and FTL groups). The physical exercise alters the energy expenditure in animal models. Poehlman and Danforth 
(POEHLMAN; DANFORTH, 1991) showed that exercise is responsible for up to $20 \%$ of energy expenditure in sedentary individuals, and almost $40 \%$ in trained humans. Besides, skeletal muscle can increases energy expenditure in up to 100 times during physical activity (GAESSER; BROOKS, 1975). All of these findings supports the idea that earlier trained rats shows a decreased body weight (AUC), at least in part due to physical activity. An elegant study of Ribeiro et al. (RIBEIRO et al., 2011) also demonstrated that physical training begging at $28 \mathrm{~d}$ and lasting up to $120 \mathrm{~d}$ of life reduces the body weight (AUC) in diabetic rats. Trained late group did not show reduction in body weight (AUC), possibly due to the short period of exercise training, along with the older age of the rats when physical activity was initiated, which is a limitation of our study. It is likely that at least $60 \mathrm{~d}$ of physical training period is necessary to reduce body weight.

The adipose tissue weight did not vary between trained and sedentary groups. Physical activity increase daily metabolic rate, however, trained rats showed increased food intake, which could counteracts exercise effect to weight loss. In physical activity at the AnT intensity, the glucose, obtained by glycogen degradation, is the main muscular substrate. However, lipids and proteins contribute to a small amount of energy source (BROOKS; MERCIER, 1994). After exercise training period, the organism degrades lipids as a carbon source used in energy production (KRSSAK et al., 2000). Besides, glycogen stores must be reestablished in order to maintain euglycemia and do not affect the central nervous system function (KRSSAK et al., 2000). Liver has elevated stores of glycogen and lipids (BENINGTON; HELLER, 1995). In our study, we found that the liver of the animals showed a decrease in lipid concentration in trained groups (CTE, FTE and FTL), suggesting this substrate was mobilized and used by muscle fibers and other cells for energy production, at the same time that glycogen re-synthesis was occurring. Further research is necessary to evaluate whether the glucose metabolism/glycogen consumption or protein degradation contributes to maintain energy homeostasis in these animals.

Several studies point to fructose diet consumption as a potent inducer of hepatic lipid accumulation and liver steatosis (BASCIANO; FEDERICO; ADELI, 2005; BENNETT et al., 1995; BROWN; GOLDSTEIN, 1997; RENNIE; WINDER; HOLLOSZY, 1976). Physical activity at the AnT maintained the same levels of hepatic lipids in both fructose fed group (FTE and FTL) and respective controls (CTE and CTL). The analyses did not point any difference in lipid concentrations from adipose tissue regions (subcutaneous, retroperitoneal and mesenteric) in fructose and control groups. It is possible that there were no changes in adipose tissue because the animals were very young (28d to $120 \mathrm{~d}$ ). A previously study of our research group introduced the fructose-rich diet to the animals at $128 \mathrm{~d}$ of life to induce inflammation (BOTEZELLI et al., 2016). Nevertheless, another recent research used female find the inflammatory effects of fructose administration to female rats with 21d of life, meanwhile we used male rats in our study, suggesting a gender-specific effect (KOVAČEVIĆ et al., 2017).

The sedentary fructose fed rats shows increased food intake compared to sedentary control group, however they do not have any alterations on body weight, neither on retroperitoneal, mesenteric and subcutaneous adipose tissue weight. Conversely, other studies showed an increase in body weight under fructose diet (ELLIOTT et al., 2002; KOK; ROBERFROID; DELZENNE, 1996). Differences as time of life administration, species, fructose concentration, along with time administration of the diet must modify the development of metabolic disorders in animals.

Despite some evidences demonstrating that physical exercise reduces heart lipid concentration (FONTANA et al., 2007), there are a lack of studies showing lipid concentrations in the heart under fructose-rich diet (BENINGTON; HELLER, 1995; KASIM-KARAKAS et al., 1996). The results presented here indicates that there is no important alteration in lipid accumulation in the heart in all groups studied, due to different exercise protocols and diet.

The fructose-rich diet caused an increase in liver lipids content in the sedentary animals. On the other hand, both training protocols reduced the liver lipids content in both major groups (Control and Fructose). These results support the conclusion that swimming training at the AnT performed in early or late protocols were effective to reduces liver lipid levels in animals fed a fructose-rich diet, contributing to the prevention and treatment against metabolic disorders related to early or late intake of fructose.

\section{ACKNOWLEDGEMENTS}

Authors thanks the technical support from JRR Silva, E Custódio e C Sibuya as well the Prof. Maria Alice Rostom de Mello expertise. We also appreciate the financial support from FAPESP (grant number 2013/20293-2). 


\section{AUTHOR CONTRIBUTIONS}

J.D.B., L.T.C. and, A.C.G. were responsible for the experimental design, the fructose administration, the data collection, tissue extraction. R.C.G, G.K.K. and, V.R.M. were responsible for the images editing and the manuscript writing. A.C.,
GASPAR, R. C. et al.

L.P.M. and, J.A.C.A.L. were responsible for the data analysis and the manuscript review. J.D.B. and J.R.P. were responsible for the data analysis, manuscript design, and final review. All authors approve this submission and are in accordance to the journal guidelines.

RESUMO: Este estudo tem como objetivo examinar os efeitos do treinamento físico realizado em protocolos precoce (preventivo) ou tardio (terapêutico) sobre o ganho de massa corporal, tolerância à glicose e acúmulo de triglicerídeos em ratos alimentados com dieta rica em frutose. Ratos Wistar foram alocados em dois grupos principais de acordo com a dieta recebida: Controle (C, dieta padrão) e Frutose (F, dieta contendo 60\% de frutose) durante 120 dias. Em seguida, esses dois grupos foram distribuídos em seis grupos: C e F que foram mantidos inativos; CET (Controle Treinado Precoce) e FTE (Frutose Treinado Precoce) que foram submetidos ao treinamento no Limiar Anaeróbio (AnT) de 28 a 120 dias; CTL (controle treinado tardio) e FTL (frutose treinado tardio) treinados de 90 a 120 dias. O treinamento físico foi composto por natação ( 5 dias / semana) na AnT determinado pela Máxima Fase Estável de Lactato (MLSS). O Teste Oral de Tolerância à Glicose (oGTT) foi realizado 48 horas após a última análise in vivo e não mostrou diferenças entre os grupos. Depois, os animais foram eutanasiados para extração do coração, fígado e tecido adiposo. Os animais exercitados precocemente apresentaram menor massa corporal em comparação com os sedentários. Além disso, a dieta rica em frutose aumentou o conteúdo de lipídios do fígado nos animais sedentários e o treinamento físico reduziu com sucesso este parâmetro em ambos os grupos principais. Estes resultados sugerem que o treinamento físico no AnT realizado em protocolos precoce ou tardio são eficazes para prevenir e tratar distúrbios metabólicos relacionados à ingestão de frutose.

PALAVRAS-CHAVE: Exercício Físico. Sobrepeso. Adiposidade. Esteatose hepática.

\section{REFERENCES}

ANGELIS, K. DE et al. The importance of animal studies in Exercise Science. Motriz: Revista de Educação Física, v. 23, n. spe, 2017.

BASCIANO, H.; FEDERICO, L.; ADELI, K. Fructose, insulin resistance, and metabolic dyslipidemia. Nutrition \& Metabolism, v. 2, n. 1, p. 5, 21 fev. 2005.

BENINGTON, J. H.; HELLER, H. C. Restoration of brain energy metabolism as the function of sleep. Progress in neurobiology, v. 45, n. 4, p. 347-60, mar. 1995.

BENNETT, M. K. et al. Sterol regulation of fatty acid synthase promoter. Coordinate feedback regulation of two major lipid pathways. The Journal of biological chemistry, v. 270, n. 43, p. 25578-83, 27 out. 1995.

BEZERRA, R. M. et al. A high-fructose diet induces insulin resistance but not blood pressure changes in normotensive rats. Brazilian journal of medical and biological research $=$ Revista brasileira de pesquisas medicas e biologicas, v. 34, n. 9, p. 1155-60, set. 2001.

BLAKELY, S. R. et al. Long-term effects of moderate fructose feeding on glucose tolerance parameters in rats. The Journal of nutrition, v. 111, n. 2, p. 307-14, fev. 1981.

BOTEZELLI, J. D. et al. Consumo de frutose e exercício físico, impacto na síndrome metabólica. Motriz. Revista de Educação Física. UNESP, v. 16, n. 1, 19 nov. 2009.

BOTEZELLI, J. D. et al. Chronic consumption of fructose rich soft drinks alters tissue lipids of rats. Diabetology \& metabolic syndrome, v. 2, p. 43, 23 jun. 2010.

BOTEZELLI, J. D. et al. Strength Training Prevents Hyperinsulinemia, Insulin Resistance, and Inflammation Independent of Weight Loss in Fructose-Fed Animals. Scientific Reports, v. 6, n. 1, p. 31106, 4 nov. 2016. 
BOUCHARD, C. et al. The response to exercise with constant energy intake in identical twins. Obesity research, v. 2, n. 5, p. 400-10, set. 1994.

BRAY, G. A.; NIELSEN, S. J.; POPKIN, B. M. Consumption of high-fructose corn syrup in beverages may play a role in the epidemic of obesity. The American journal of clinical nutrition, v. 79, n. 4, p. 537-43, abr. 2004.

BROOKS, G. A.; MERCIER, J. Balance of carbohydrate and lipid utilization during exercise: the \&quot;crossover\&quot; concept. Journal of applied physiology (Bethesda, Md. : 1985), v. 76, n. 6, p. $2253-$ 61, jun. 1994.

BROWN, M. S.; GOLDSTEIN, J. L. The SREBP pathway: regulation of cholesterol metabolism by proteolysis of a membrane-bound transcription factor. Cell, v. 89, n. 3, p. 331-40, 2 maio 1997.

CHENG, T. O. Fast food and obesity in China. Journal of the American College of Cardiology, v. 42, n. 4 , 2003.

EBAL, E. et al. Effect of a moderate exercise on the regulatory hormones of food intake in rats. Appetite, v. 49 , n. 2, p. 521-524, set. 2007.

ELLIOTT, S. S. et al. Fructose, weight gain, and the insulin resistance syndrome. The American journal of clinical nutrition, v. 76, n. 5, p. 911-22, nov. 2002.

FALL, T.; INGELSSON, E. Genome-wide association studies of obesity and metabolic syndrome. Molecular and Cellular Endocrinology, v. 382, n. 1, p. 740-757, 25 jan. 2014.

FIELDS, M.; LEWIS, C. G.; LURE, M. D. Responses of insulin to oral glucose and fructose loads in marginally copper-deficient rats fed starch or fructose. Nutrition (Burbank, Los Angeles County, Calif.), v. 12, n. 7-8, p. 524-8, 1996.

FONTANA, L. et al. Calorie restriction or exercise: effects on coronary heart disease risk factors. A randomized, controlled trial. AJP: Endocrinology and Metabolism, v. 293, n. 1, p. E197-E202, 20 mar. 2007.

GAESSER, G. A.; BROOKS, G. A. Muscular efficiency during steady-rate exercise: effects of speed and work rate. Journal of applied physiology, v. 38, n. 6, p. 1132-9, jun. 1975.

GOBATTO, C. A. et al. Maximal lactate steady state in rats submitted to swimming exercise. Comparative biochemistry and physiology. Part A, Molecular \& integrative physiology, v. 130, n. 1, p. 21-7, ago. 2001.

KASIM-KARAKAS, S. E. et al. Effects of dietary carbohydrates on glucose and lipid metabolism in golden Syrian hamsters. The Journal of laboratory and clinical medicine, v. 128, n. 2, p. 208-13, ago. 1996.

KOK, N.; ROBERFROID, M.; DELZENNE, N. Dietary oligofructose modifies the impact of fructose on hepatic triacylglycerol metabolism. Metabolism: clinical and experimental, v. 45, n. 12, p. 1547-50, dez. 1996.

KOVAČEVIĆ, S. et al. Fructose-enriched diet induces inflammation and reduces antioxidative defense in visceral adipose tissue of young female rats. European Journal of Nutrition, v. 56, n. 1, p. 151-160, 3 fev. 2017.

KRSSAK, M. et al. Intramuscular Glycogen and Intramyocellular Lipid Utilization during Prolonged Exercise and Recovery in Man: A 13C and 1H Nuclear Magnetic Resonance Spectroscopy Study. The Journal of Clinical Endocrinology \& Metabolism, v. 85, n. 2, p. 748-754, fev. 2000. 
LEE, Y.-C. et al. Plasma leptin response to oral glucose tolerance and fasting/re-feeding tests in rats with fructose-induced metabolic derangements. Life Sciences, v. 78, n. 11, p. 1155-1162, 9 fev. 2006.

LEVIN, B. E.; DUNN-MEYNELL, A. A. Reduced central leptin sensitivity in rats with diet-induced obesity. American journal of physiology. Regulatory, integrative and comparative physiology, v. 283, n. 4, p. R941-8, out. 2002.

LÓPEZ-JARAMILLO, P. et al. Consenso latino-americano de hipertensão em pacientes com diabetes tipo 2 e síndrome metabólica. Arquivos Brasileiros de Endocrinologia \& Metabologia, v. 58, n. 3, p. 205-225, abr. 2014.

MATTHEWS, J. N. et al. Analysis of serial measurements in medical research. British Medical Journal, v. 300, n. 6719, p. 230-5, 27 jan. 1990.

MCLELLAN, F. Obesity rising to alarming levels around the world. Lancet (London, England), v. 359, n. 9315, p. 1412, 20 abr. 2002.

NAGAI, Y. et al. Amelioration of high fructose-induced metabolic derangements by activation of PPAR $\alpha$. American Journal of Physiology - Endocrinology And Metabolism, v. 282, n. 5, p. E1180-E1190, 1 maio 2002.

NOGUEIRA, D. M. et al. Métodos de Bioquímica Clínica: Técnicas e Interpretação. São Paulo: Pancast, [s.d.].

POEHLMAN, E. T.; DANFORTH, E. Endurance training increases metabolic rate and norepinephrine appearance rate in older individuals. The American journal of physiology, v. 261, n. 2 Pt 1, p. E233-9, ago. 1991.

REEVES, P. G. Components of the AIN-93 diets as improvements in the AIN-76A diet. The Journal of nutrition, v. 127, n. 5 Suppl, p. 838S-841S, maio 1997.

RENNIE, M. J.; WINDER, W. W.; HOLLOSZY, J. O. A sparing effect of increased plasma fatty acids on muscle and liver glycogen content in the exercising rat. The Biochemical journal, v. 156, n. 3, p. 647-55, 15 jun. 1976.

RIBEIRO, C. et al. Continuous and Intermittent Exercise Training and Glucose Metabolism in Neonatal Alloxan Administered Rats. Journal of Endocrinology and Metabolism, v. 1, n. 3, p. 101-112, 30 ago. 2011.

STOIANOV, A.; ADELI, K. Central and Metabolic Effects of High Fructose Consumption: Evidence from Animal and Human Studies. Nutrition and Food Sciences Research, v. 1, n. 2, p. 3-9, 2014.

TRAN, L. T.; YUEN, V. G.; MCNEILL, J. H. The fructose-fed rat: a review on the mechanisms of fructoseinduced insulin resistance and hypertension. Molecular and Cellular Biochemistry, v. 332, n. 1-2, p. 145159, 18 dez. 2009. 